\title{
DETERMINANTS OF CONSUMERS' PURCHASE INTENTION FOR LOCAL ORGANIC FOOD IN URBAN SRI LANKA
}

\author{
S H P Malkanthi \\ Faculty of Agricultural Sciences, \\ Sabaragamuwa University of Sri Lanka \\ malkanthi09@gmail.com
}

\begin{abstract}
Organic food marketing has currently become one of the most developing markets around the world, including Sri Lanka. Thus, the main aim of this study was to recognize the determinants of the purchase intention for local organic food among urban Sri Lankans. A consumer survey was conducted covering capital cities of six urban districts in Sri Lanka; Colombo, Galle, Gampaha, Kandy, Kurunegala, and Rathnapura using a sample of 600 consumers, from December 2016 to May 2018. Out of the 600 consumers, only 114 were purchasing organic food by that time, and those 114 consumers were chosen as the sample for this study. Descriptive statistics, principal component analysis, and multiple linear regressions were used as data analysis techniques. According to the results, majority of the respondents belongs to the 31-45 year age category. While most respondents had an education up to GCE Advanced Level, significant percentages of respondents were educated up to graduate and post-graduate levels. Also, most of the respondents received a monthly total income in between Sri Lankan Rupees 85,001 and 162,000 (approximately US dollars 473 - 900). Although one-fourth of the consumers are purchasing organic food at that time, a higher number is willing to buy them in future. As per the principal component analysis, health and environment consciousness, certification of organic food, marketing aspects of organic food, common parameters of organic food, awareness on the value of organic food, and market availability of organic food were the extracted determinants. The results of multiple linear regressions revealed that market availability, common parameters of organic food, and health and environment consciousness are the dominating variables of the purchase intention of organic food consumers. Thus, expanding the market conditions for organic food, establishing a better marketing system, conducting effective food awareness programs, and value addition for organic food are the identified timely essential recommendations.
\end{abstract}

Keywords: Determinants, organic food, consumers, purchase intention, Urban Sri Lankans

\section{INTRODUCTION}

Organic food consumption is currently becoming a popular practice in many countries. Moving from conventional food to organically produced food consumption is one of the major trends in the present society. Throughout the world, and in Sri Lanka, organic food is becoming popular over conventional food. Organic food can be defined as the products that are in the process of production without adding any artificial fertilizers, pesticides, and additives (Mohamad et al., 2014).

At present, lifestyle of the consumer has materialized, especially regarding the attitude of consuming organic food, because people are becoming more aware of the benefit of consuming healthy food in their day-to-day lives. Even though a naturally grown clean, and balanced diets are vital for healthy life, many regular meals are mostly made by using unsafe additives, flavors, preservatives, and various coloring in the market (Shaharudin et al., 2010). The health aspect has become one of the critical matters of consumers at present when purchasing products, especially regarding food items. This factor is the main motivating force for consumers to buy organic food at the market (Yin et al., 2010).

Many countries around the world have recorded a gradual increase in the usage of organic food. Due to less harmfulness of organic food to humans, and also due to its health and environmental benefits, buyers tend to purchase organic food than conventional food items (Hapuarachchi, 2016). Developing countries like India and China have markets on the global level due to a high demand for their organic products (Sujaya et al., 2018) According to Tech Sci Research (2014), Indian organic food market is anticipated growing over 25\% during 2016-2021. As per the world organic marketing statistics, the return for organic products in 2016 in US was EUR 38.9 billion sales, while it was EUR 9.7 billion sales in Germany and EUR 6.7 billion sales in France. Although organic farming is being practiced in 178 countries, the largest 
single market is the US (47\%) next being the European Union (EUR 30.7 billion, 37\%) followed by China (EUR 5.9 billion, 6\%) (Sujaya et al., 2018).

In focusing attention on customers' purchase intention, it is a complex process based on the perceptions, behavior, and attitudes of consumers. Purchase intention can be defined as an individual's readiness and like to purchase a particular product or service (Al-Ekam et al., 2012). Purchase intention may be changed under the fluctuations of price or perceived quality and value of the organic food. Also, consumers are influenced by internal or external motivation factors during the purchasing process (Gogoi, 2013).

Badgley et al., (2007) reveal that organic farming has a higher possibility to contribute to global food production. Davis et al., (1995) revealed that purchase intentions are affected by environmental and health consciousness, safety and quality concerns, and important product characteristics such as nutritional value, freshness, taste, and price level. According to Mintel (2000), as the young and old aged groups of people least concern with organic food, they have lower emphasis on their diet and health. Organic consumers think that production of most of the conventional food products is environmentally harmful as it involves high use of chemicals and pesticides, while organic food production is perceived as being environmentally friendly (Wilkins and Hillers 1994). Many studies revealed that concern on environment has a favorable in $\square$ uence on the consumer purchase intention (Zanoli and Naspetti 2002; Magnusson et al., 2003).

Study of Rosario (2006) revealed that Sri Lankan customers do not like to pay a higher cost for organically grown vegetables. Most investigations have concluded that price is the primary determinant factor for the purchasing intention, and the cost of organic food has been cited in many articles to be the major obstacle for not purchasing organic food (Hughner et al., 2007). In modern days, individuals have become highly health conscious and environmental concerned (Gould, 1988; Dunlap and Jones, 2002).

Main reasons behind these trends are the ever-increasing disease burden and ecological degradation. When considering dietary practices, food habits are responsible for various health problems such as non-communicable diseases, food poisoning, and food allergies. It has been proved that organically manufactured food products do not contain harmful pesticides, additives, and preservatives that can cause health problems (Centre for Organic food and Farming, 2015).

Krystallis and Chryssohoidis (2005) stated that, factors like food quality and security, reliance in certification and also in some case the brand name, heavily influence in determining a purchase than price and socio-economic variables. As per Chryssochoidis (2000) and Padel and Foster (2005), consumer knowledge determines the purchasing intention of organic food. Stobbelaar et al., (2006) claimed that, if consumers are more knowledgeable about organic food, their purchasing intention is mainly positive. Knowledge of consumers about organic food could be increased from various sources. Gracia and Magistris (2007) proved that, information on organic food displayed at the market could have a high influence on consumers' knowledge. Pandey et al., (2019) revealed that understanding consumer is crucial for sellers for the gradual growth of the organic food market.

Sri Lanka has full of natural resources than other countries. It has a high potential to fulfill this ever-growing market demand in the society for organic products. Countries across the world, including Sri Lanka, have recorded a comparative increase in use of organic food (FiBL and IFOAM, 2013). Many researchers reported that people who are health conscious and environmental concerned tend to have a positive attitude on organically processed food. This booming industry has created a necessity to study the intention of consumers' on organic food in Sri Lanka as agricultural producers, where it provides valuable insights to drive the organic food market effectively. Consumers' purchasing intention towards organic product has an impact on consumer behavior towards organic foods

Sri Lankans are experiencing health issues and environmental problems when they deviate from traditional food habits and conventional agricultural methods. World Health Organisation (2015) highlighted that noncommunicable diseases and unhealthy foods had caused 38 million deaths around the world. Sri Lankan government is turning towards organic farming, and motivating farmers to practice organic farming. However, the value of organic food is perceived differently by consumers, and hence, it is time to find out about the consumer purchasing intention towards organic products. Therefore, this study aimed to reveal the determinants of purchase intention of local organic food, based on urban consumers in Sri Lanka. Thus, the main question of this study was "what the factors determine the purchase intention of urban Sri Lankan consumers' towards local organic foods are"?

\section{OBJECTIVES OF THE RESEARCH}

The primary aim of the research was to study the determinants of consumer purchasing intention towards local organic food in urban Sri Lanka. Evaluation of the socioeconomic characteristics of the consumers of organic food, the present situation of purchasing organic food and willingness to purchase of organic food in future, identification of the determinants of purchase intention of organic foods, and analysis of the relationship between extracted determinants and purchase intention of organic food were the specific objectives of the study. Using the conceptual framework (Figure 1), six hypotheses were formed as follows:

\section{Hypothesis used in the study}

$\mathrm{H}_{0} 1$; There is no relationship between Health and environmental consciousness and the purchase intention of organic food.

$\mathrm{H}_{0} 2$; There is no relationship between Product certification of organic food and the purchase intention of organic food.

$\mathrm{H}_{0} 3$; There is no relationship between Marketing of organic food and the purchase intention of organic food.

$\mathrm{H}_{0}$; There is no relationship between Common parameters 
of organic food and the purchase intention of organic food.

$\mathrm{H}_{0}$ 5; There is no relationship between Awareness about the value of organic food and the purchase intention of organic food.

$\mathrm{H}_{0} 6$; There is no relationship between the Market availability of the product and the purchase intention of organic food.

\section{Conceptual Framework of the study}

A conceptual framework provides the structure of the research concept and relationships between the variables. After a thorough literature review, essential determinates were identified (Figure1), and hypotheses were developed to test them in Sri Lankan context.

Figure 1. Conceptual framework of the research conducted using the pre-tested questionnaire in the selected six cities, from December 2016 to May 2018. Several data collection techniques were adopted, including questionnaire surveys, focus group discussions, and informal interviews. The questionnaire was developed by considering the past research work and the present situation. Out of the 600 consumers, only 114 were purchasing organic food by that time. Those 114 consumers were considered as the sample for this study. In data analysis, frequencies and percentages were used to assess the consumers' socio- economic characteristics, present situation of purchasing organic food, and willingness to purchase organic food in future. Determinants influencing the purchase intention of consumers have been analyzed with principal component extraction with varimax rotation. Reliability Coefficients (Cronbach's Alpha) were used to measure the reliability of the determinant factors, and

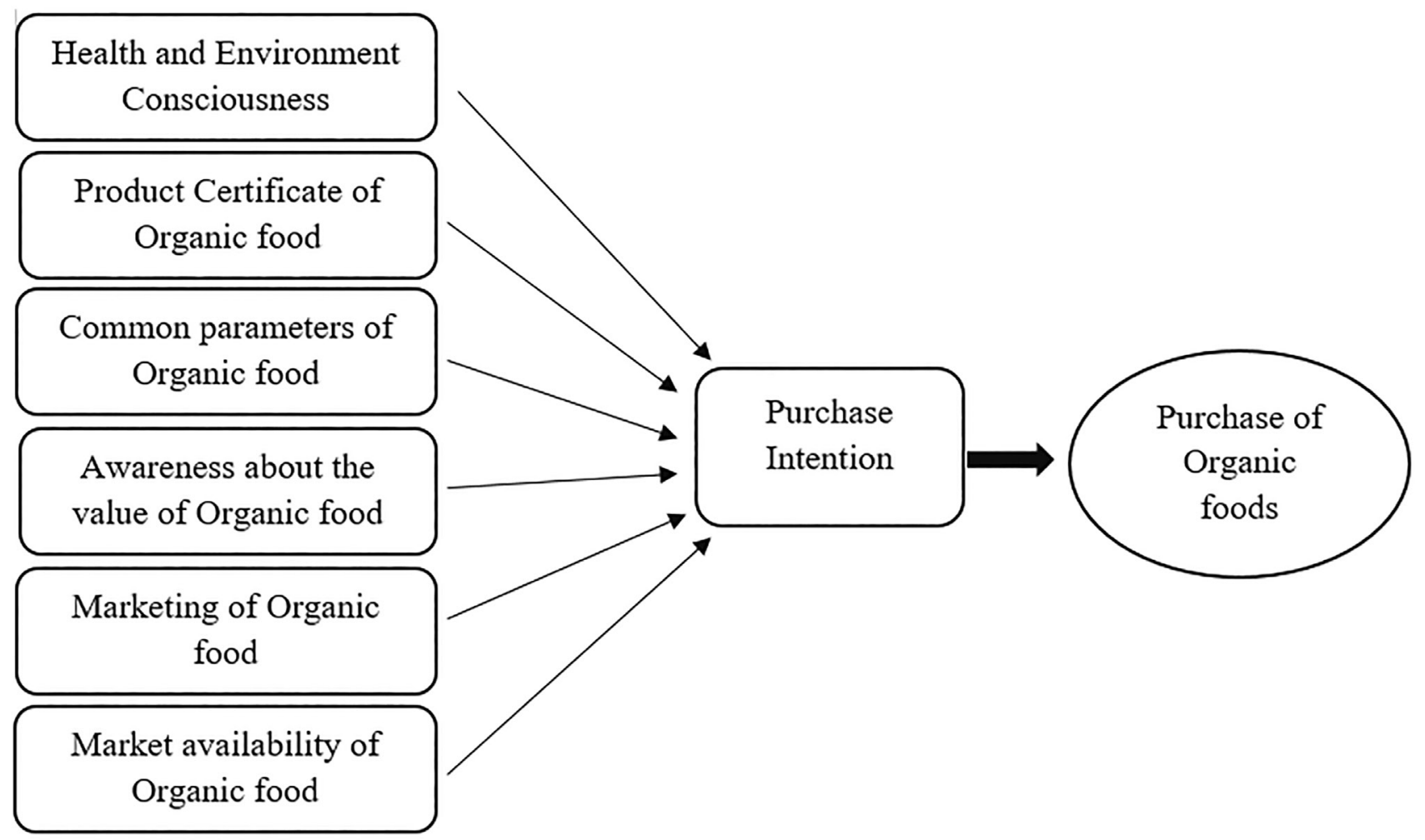

\section{METHODOLOGY}

This study was carried out in the capital cities of six districts (Colombo, Galle, Gampaha, Kandy, Kurunegala, and Rathnapura) in Sri Lanka. Capital cities of those districts were selected purposively for the research as they have the potential for the presence of organic markets and organic food consumers. Four organic food markets were randomly selected from each city. The target group was chosen from customers who came out of the market. Questionnaires were filled with the customers who were willing to answer the questions. Data were collected at 24 organic food markets (04 supermarkets from each city), and the sample size was 600 customers (100 from each city). A consumer survey was a multiple linear regression model helped to analyze the relationship between extracted determinants and purchase intention of organic foods.

\section{RESULTS AND DISCUSSION}

The results of the study are arranged in four sections as socio-economic factors of the organic consumers in urban areas, present situation of purchasing organic food and willingness to purchase organic food in future, determinants of purchasing organic foods by urban consumers, and the relationship between extracted determinants and purchasing intention of organic foods in Sri Lanka based on the selected six capital cities. 
Socio-economic factors of organic consumers in urban areas.

Socio-economic factors of the sample are important in multiple ways. Therefore, main socio-economic factors such as age, gender, education level, and monthly income of the respondents were reviewed in detail. Results are presented in Table 1.

Table 1. Socio-economic factors of the respondents $(n=144)$

\begin{tabular}{|c|c|c|c|}
\hline \multicolumn{2}{|l|}{ Socio-economic factor } & \multirow{2}{*}{$\begin{array}{l}\text { Frequency } \\
21\end{array}$} & \multirow{2}{*}{$\begin{array}{l}\text { Percentage } \% \\
14.6\end{array}$} \\
\hline \multirow{4}{*}{ Age (years) } & $16-30$ & & \\
\hline & $31-45$ & 102 & 70.8 \\
\hline & $46-60$ & 16 & 11.1 \\
\hline & more than 60 & 05 & 03.5 \\
\hline \multirow{2}{*}{ Gender } & Male & 37 & 25.7 \\
\hline & Female & 107 & 74.3 \\
\hline \multirow{3}{*}{ Marital status } & Married & 125 & 86.5 \\
\hline & Unmarried & 09 & 06.4 \\
\hline & Other & 10 & 07.1 \\
\hline \multirow{3}{*}{ Family size } & 2-3 members & 56 & 38.7 \\
\hline & 4-5 members & 77 & 53.6 \\
\hline & $>5$ members & 11 & 07.7 \\
\hline \multirow{2}{*}{$\begin{array}{l}\text { Are there children in } \\
\text { the family? }\end{array}$} & Yes & 93 & 64.8 \\
\hline & No & 51 & 35.2 \\
\hline \multirow{3}{*}{ Educational level } & $\mathrm{A} / \mathrm{L}$ & 68 & 47.2 \\
\hline & Graduate & 55 & 38.2 \\
\hline & Postgraduate & 21 & 14.6 \\
\hline \multirow{3}{*}{$\begin{array}{l}\text { Monthly income } \\
\text { (LKR) }\end{array}$} & $40,001-58,000$ & 49 & 34.0 \\
\hline & $85,001-162,000$ & 64 & 44.4 \\
\hline & $>162,000$ & 31 & 21.5 \\
\hline
\end{tabular}

Source: Consumer survey 2016-2018

As per Table 1, most of the consumers (70.8\%) belonged to the age category of $31-45$ years. The majority $(74.3 \%)$ of 144 respondents was females. It is evident that most consumers (86.5\%) were married, had 4-5 family members (53.6\%), and were with children (64.8\%). According to the results, families with children tend to buy organic food more than others.

Consumers who purchased organic food, had higher educational levels. While the majority of the consumers (47.2\%) had studied up to GCE A/L, there were significant number of graduates and postgraduate consumers as well. It seems that, consumers with a good educational background, concern more about organic foods than the others. The highest percentage of urban consumers (44.4\%) had received a monthly income between 85,001 - 162,000 LKR, which is a comparatively higher level of income compare with the average monthly income of a normal family in the country.

The present situation of purchasing organic food and willingness to purchase organic food

The present situation of purchasing organic food and willingness to purchase organic food in the future were studied, and the findings are presented in Table 2.

Table 2: The present situation of purchasing organic food, and the willingness to purchase organic food

\begin{tabular}{|l|l|l|}
\hline $\begin{array}{l}\text { Present situation of } \\
\text { buying }(\mathrm{n}=600)\end{array}$ & Frequency & Percentage \\
\hline Yes & 144 & 24.0 \\
\hline No & 377 & 62.8 \\
\hline No response & 79 & 13.2 \\
\hline Present frequency of buying (n=144) & 16.0 \\
\hline Most of the time & 23 & 27.0 \\
\hline Sometimes & 39 & 57.0 \\
\hline Rarely & 82 & 52.4 \\
\hline WTP in future $(\mathrm{n}=600)$ & 314 & 37.3 \\
\hline Yes & 224 & 10.3 \\
\hline No & 62 & \multicolumn{2}{|l}{} \\
\hline No response & \multicolumn{2}{|l|}{} \\
\hline
\end{tabular}

Source: Consumer survey 2016-2018

As per Table 2, only a substantial number of consumers (24\%) have bought organic food. Even among them, only a very few number $(16 \%)$ has bought them frequently, while the rest were occasional buyers. Nevertheless, among the respondents, a higher percentage (52.4\%) was willing to pay a premium price for organic food in future, if products are truly organic. According to Coulibaly et al., (2011), consumers in West Africa, Ghana, and Benin have agreed to pay a higher price for organic vegetables. Consumers' willing to pay for premium price for organic products differ across diverse product categories (Gil et al., 2000: Krystallis and Chryssohoidis, 2005).

Determinants of purchase intention of organic foods by the urban consumers

A study on the significant determinants of the purchase intention of organic foods by urban consumers was carried out in this stage. Firstly, the Kaiser-Mayer-Olkin (KMO) and Bartlett's Test was carried out to check the suitability of the data for the principal component analysis. Table 3 presents the findings of the KMO and Bartlett's Test.

Table 3. KMO and Bartlett's Test

\begin{tabular}{|l|l|l|}
\hline \multicolumn{2}{|l|}{ Kaiser-Meyer-Olkin Measure of Sampling Adequacy } & 0.803 \\
\hline \multirow{3}{*}{ Bartlett's Test of Sphericity } & Approx. Chi-Square & 1886.493 \\
\cline { 2 - 3 } & Df & 351 \\
\cline { 2 - 3 } & Sig. & 0.000 \\
\hline
\end{tabular}

Source: Consumer survey 2016-2018

According to Table 3, the KMO value of sampling adequacy is 0.803 , which exceeds the suggested cut-off value 
of 0.60 (Tabachnick and Fidell, 2007). The Bartlett's test of sphericity was significant (Chi-square value 1886.493, p 0.000), indicating that the inter-item correlations were sufficiently large for principal component analysis (PCA). A PCA followed the KMO and Bartlett's test, and Table 4 presents the result.

Table 4. Results of the principal component analysis (PCA)

\begin{tabular}{|c|c|c|c|}
\hline Factor & Mean & SD & \begin{tabular}{|l|} 
Factor \\
loading
\end{tabular} \\
\hline \multirow{4}{*}{$\begin{array}{l}\text { 1. Health and environment con- } \\
\text { sciousness } \\
\text { The idea which is "No Harmful } \\
\text { effects" become the reason for } \\
\text { purchasing intention. } \\
\text { The idea which is "Good for } \\
\text { Health" become the reason for } \\
\text { purchasing intention } \\
\text { The idea which is "No pesticides } \\
\text { in organic foods become the rea- } \\
\text { son of purchasing intention } \\
\text { Organic agriculture gains benefit } \\
\text { for the environment }\end{array}$} & 4.23 & 0.875 & 0.805 \\
\hline & 4.58 & 0.621 & 0.787 \\
\hline & 4.19 & 0.887 & 0.701 \\
\hline & 4.53 & 0.678 & 0.636 \\
\hline \multirow{4}{*}{$\begin{array}{l}\text { 2. Product certification of organic food } \\
\text { Label influences the purchasing } \\
\text { intention of organic food. } \\
\text { Brand Name influences the pur- } \\
\text { chasing intention of organic food. } \\
\text { Consumers trust the labels of } \\
\text { organic food. } \\
\text { Labels mean high-quality food. }\end{array}$} & 3.44 & 1.069 & 0.826 \\
\hline & 3.31 & 1.119 & 0.782 \\
\hline & 3.16 & 1.075 & 0.733 \\
\hline & 3.10 & 1.047 & 0.722 \\
\hline \multirow{4}{*}{$\begin{array}{l}\text { 3. Marketing aspects of organic food } \\
\text { Packaging of organic food influ- } \\
\text { ences the purchasing intention. } \\
\text { Labeling of organic food influ- } \\
\text { ences the purchasing intention. } \\
\text { Government rules and regulations } \\
\text { on the safeness of organic food } \\
\text { influence purchasing intention. } \\
\text { Certification of organic food af- } \\
\text { fects purchasing intention. }\end{array}$} & 2.99 & 1.014 & 0.867 \\
\hline & 3.06 & 1.029 & 0.787 \\
\hline & 3.30 & 1.104 & 0.720 \\
\hline & 3.60 & 1.066 & 0.665 \\
\hline \multirow{3}{*}{$\begin{array}{l}\text { 4. Common attributes of organic } \\
\text { food } \\
\text { Taste of organic food affects the } \\
\text { purchasing intention. } \\
\text { The good smell of organic food } \\
\text { affects the purchasing intention. } \\
\text { Quality of organic food affects the } \\
\text { purchasing intention. }\end{array}$} & 4.32 & 0.754 & 0.834 \\
\hline & 4.10 & 0.906 & 0.829 \\
\hline & 4.50 & 0.748 & 0.599 \\
\hline \multirow{2}{*}{$\begin{array}{l}\text { 5. Awareness about the values of } \\
\text { organic food } \\
\text { Information on Nutritional value } \\
\text { of organic food affects the pur- } \\
\text { chasing intention. } \\
\text { Knowledge about organic food af- } \\
\text { fects the purchasing intention. }\end{array}$} & 4.35 & 0.683 & 0.834 \\
\hline & 4.30 & 0.6150 & 0.762 \\
\hline $\begin{array}{l}\text { 6. Market availability of the } \\
\text { product } \\
\text { Availability of organic food in the } \\
\text { market influences the purchasing } \\
\text { intention. }\end{array}$ & 3.74 & 0.939 & 0.757 \\
\hline
\end{tabular}

Source: Consumer survey 2016-2018
The result of PCA in Table 4 evidenced that six (06) factors were extracted as those components are good for the purchase intention of the organic foods, from the consumers' responses to the 27 statements as variables for principal component analysis, (with Kaiser Normalization and varimax rotation). Those items were extracted with factor loadings value below 0.5 , and the contribution of each item made to the corresponding factor was achieved by applying the reliability coefficient Cronbach's alpha for further clarification.

Factor 1 (Health and environment consciousness) was based on the ideas of "no harmful effects - absence of any chemical food additives, protect soil microbial population, enhance soil conservation and increase natural soil fertility level" "good for health," and "no pesticides" as the reasons for purchasing organic food. The study of Kapuge (2016) and Wijesinghe et al., (2016) explained that the awareness and health consciousness are the key determinants of purchasing organic foods, and they have a positive impact on the purchase intention. However, they reported that, "environment consciousness" does not have a significant impact on individuals' purchasing attitude of organic food. But, the findings of this study revealed that, environmental consciousness is also an important determinant of purchase intention. Meanwhile, based on a research, Sivathanu (2015) has reported a similar finding. Both findings indicated that, consumers prefer to purchase organic products due to the involvement of environment-friendly processes.

Factor 2 (Product certifications of organic food) was derived from four measures, including labels influences the purchase intention of organic foods, brand name influences the purchase intention of organic foods, consumers trust the labels of organic food, and labels mean high-quality food. The importance of certification and organic labeling was also considered as a strong determinant in the study of Narmilan and Amuthenie (2015). This study revealed that product certification and organic labeling are better solutions to overcome failures to recognize the quality of organic products.

Factor 3 (Marketing of organic food) was derived from the packaging and labeling of organic foods, government rules and regulations on the safeness of organic foods related to certification of organic foods which influence the consumers' purchase intention.

Factor 4 (Common parameters of organic food) was derived from the factors including taste, good smell, and quality of organic food, which influence the consumers' purchase intention.

According to Ozguven (2012), health, price, quality, and food safety are the four factors that motivate consumers to purchase organic food. Findings of Narmilan and Amuthenie (2015) indicated that the role of quality, price, health, and the safety of foods are more important for the purchasing behavior of organic foods. Among those variables, health and price are the most dominant determinants. However, according to Sivathanu (2015), health, safe, and nutritious factors are the leading determinants of the purchase intention of organic foods.

Factor 5 (Awareness on the value of organic products) 
comprised of two measures as the information on nutritional value of organic food affecting the purchase intention, and the knowledge on organic foods, which affect the purchase intention.

Although the determinants of organic food purchase intention are changed (dynamic), health consciousness is found to be a better predictor of organic food purchase intention, and the consumers' awareness regarding organic food is a determinant that helps to moderate a positive impact of purchase intention (Asif et al., 2018).

Factor 6 (market availability of the product) was also comprised of one measurement, i.e., the presence of organic food in the market causes the purchasing intention.

The relationship between extracted determinants and purchasing intention of organic food

The relationship between extracted determinants and purchasing intention of organic food was analyzed using multiple linear regression analysis. According to the six hypotheses, the resultant factor scores were then regressed against the dependent variable (mean of purchasing intention). Table 5 presents the relevant results.

Table 5. The results of multiple linear regression analysis

\begin{tabular}{|l|l|l|l|l|}
\hline & $\begin{array}{l}\text { Beta coef- } \\
\text { ficient }\end{array}$ & T & Sig. & $\begin{array}{l}\text { Hypothesis } \\
\text { H0 }\end{array}$ \\
\hline $\begin{array}{l}\text { Health and } \\
\text { environment } \\
\text { consciousness }\end{array}$ & 0.167 & 2.069 & 0.040 & Reject * \\
\hline $\begin{array}{l}\text { Product certifica- } \\
\text { tion of organic } \\
\text { foods }\end{array}$ & -0.035 & -0.429 & 0.669 & $\begin{array}{l}\text { Do Not } \\
\text { Reject }\end{array}$ \\
\hline $\begin{array}{l}\text { Marketing as- } \\
\text { pects of organic } \\
\text { foods }\end{array}$ & -0.056 & -0.691 & 0.491 & $\begin{array}{l}\text { Do Not } \\
\text { Reject }\end{array}$ \\
\hline $\begin{array}{l}\text { Common attrib- } \\
\text { utes of organic } \\
\text { foods }\end{array}$ & 0.174 & 2.157 & 0.033 & Reject * \\
\hline $\begin{array}{l}\text { Awareness about } \\
\text { the value of } \\
\text { organic foods }\end{array}$ & -0.003 & -0.033 & 0.974 & $\begin{array}{l}\text { Do Not } \\
\text { Reject }\end{array}$ \\
\hline $\begin{array}{l}\text { Market avail- } \\
\text { ability of the } \\
\text { product }\end{array}$ & 0.202 & 2.504 & 0.013 & Reject* \\
\hline & & & & \\
\hline
\end{tabular}

Adjusted R2 $=0.067$

Standard error $=0.6376$, based on $95 \%$ confidence level

Source: Consumer survey 2016-2018
Table 5 provides the multiple linear regression model summary and over-fit statistics. The results have shown supportive evidence to prove that the determinants of purchasing intention. The multiple linear regression analysis indicated positive relationships between purchase intention and market availability of the products, common parameters of the organic products, health, and environmental consciousness. This finding is in line with Aertsens et al., (2005), who reported that environmental concern has a significant effect on the use of organic food. However, Kapuge (2016) reported that environmental concern is not a determining factor affecting the purchase intention of organic food in Sri Lanka.

Thus, the multiple linear regression analysis revealed that the market availability of the product (Beta coefficient 0.202), common parameters of organic food (taste, smell, and quality) (Beta coefficient 0.174), and purchase intention of organic products (Beta coefficient 0.167) due to higher Beta coefficient value rather than the other factors respectively. And also, both the common parameters of organic food and market availability of organic food were indicated significant relationship to the purchase intention of organic foods.

Determinants of purchasing intention of organic foods are imperative for the marketers, companies and farmers, because these findings have implications in future to fulfill the real consumer requirements.

Conclusion and Recommendations

As per the socio-economic factors, more than half of the consumers of the sample were female, and the majority of them were in between 31- 45 years of age. Also, most of them had an education up to the GCE Advance Level and received a monthly income of Sri Lankan Rupees 85,001 - 162,000 (Approximately US dollars 473 - 900).

Less number of consumers are purchasing organic food at present, and out of them, only a very few buy organic food often. However, more customers are willing to buy them in the future if the products are genuinely organic.

As per the principal component analysis, mainly six factors influence the purchase intention of consumers towards organic food. They are health and environmental consciousness, product certification of organic foods, marketing aspects of organic food, common parameters of organic food, awareness about the value of organic food, and market availability of the products.

Results of the multiple linear regression analysis indicated a positive relationship between purchase intention and the three determinants (the market availability of the product, common parameters of organic food, and health and environmental consciousness). The key determinant of purchasing organic food was the market availability of the product.

Development of the marketing mix (4Ps) can gain a certain level of uplifement in the organic market in Sri Lanka. According to consumer analysis, there is a significant positive implication for the development of the market. Hence, the marketer/seller need to pay more attention on 4Ps (Product, Price, Place, Promotion) related to organic food.

Improving the marketing system is a great strength for organic agriculture. Almost all stakeholders have to 
participate in the development of an efficient marketing system. Furthermore, expanding the market conditions for easy access for farmers to sell their products, an innovation of more organic products with quality research, and valueaddition for organic foods are the driving forces to establish an improved marketing system.

The research discovered that consumers tend to purchase organic foods due to their quality parameter like smell, taste, and quality, which means the products do not include inorganic chemicals. In the present context, price is the most prominent barrier to increase the consumption of organic food. Marketers have to pay attention in this regard to offer their products at reasonable price levels.

Promotion is also an essential aspect of marketing, because a favorable image is created by promoting in the form of advertisements. Marketing aspects, including branding, labeling, and product certification are significant factors that affect the purchasing behavior of consumers. Even within this rapid dynamic society, consumers have concerned more about the health aspects of organic food. This could be achieved by conducting effective product promotion and awareness programs in road tours, trade shows, exhibitions, campaigns, and advertising regularly to introduce organic food products. Policymakers need to draw special attention to retain the present consumers and create new consumers as well.

Lack of presence of organic products at the market is an issue faced by consumers who are willing to buy organic food. However, if organic products are available in the market with easy access, consumers tend to buy organic food than other foods.

A suitable government certification system for organic food products is required to drive the organic food market efficiently. The current trend of consumer purchasing intention is directed towards their concern about the environmental impact of the production process of particular products.

Acknowledgment

The Ministry of Agriculture (MOA) and the Sri Lanka Council for Agricultural Research Policy (SLCARP) supported this research work, under the research Grant number NARP/16/SUSL/AS/01. The author is grateful to all who helped to make the work successful.

\section{REFERENCES}

Aertsens, J., Verbeke, W., Mondelaers, K., and Huylenbroeck, V.G., 2005. Personal determinants of organic food consumption: a review. British Food Journal.

Al-Ekam, J.M., Umar, T.R., Kamariah, N.M., and tahir, F.A., 2012. The Influence of Trust, Advertising, Family on Intention and Actual Purchase of Local Brand in Yemen, American Journal of Economics, 64-68.

Asif, M., Xuhui, W., Nasiri, A., and Ayyub, S., 2018. Determinant factors influencing organic food purchase intention and the moderating role of awareness: A comparative analysis. Food Quality and Preference, 63, 144-150.
Badgley, C., Moghtader, J., Quintero, E., Zakem, E., 2007. Organic agriculture and global food supply, Journal of Renewable agriculture and food system, 22(2):86-108.

Centre for Organic Food and Farming, 2015. "ORGANIC FOOD- food quality and potential health effects, The Swedish University of Agricultural Sciences, ISBN: 978- 91-576-9274-0.

Chryssochoidis, G., 2000. Repercussions of consumer confusion for late introduced differentiated products, Europe Journal of Marketing, 34(5/ 6): 705-722.

Coulibaly, O., Nouhoheflin, T., Aitchedji, C.C., Cherry, A.J., and Adegbola, P., 2011. Consumers' perceptions and willingness to pay for organically grown vegetables. International Journal of Vegetable Science, 17(4): 349-362.

Davis, A., Titterington, A.J., and Cochrane, C., 1995. Who buys organic food? A profile of the purchasers of organic food in N. Ireland. British Food Journal, 97(10), 17-23.

Dunlap, R., and Jones, R., 2002. Environmental Concern: Conceptual and Measurement Issues. In Dunlap and Michelson (Ed), Handbook of Environmental Sociology (pp. 482- 542). London: Greenwood Press.

FiBL, and IFOAM, 2013. the world of organic agriculture statistics and emerging trends. available at: http://www.organicworld.net/yearbook-2013.html

Gil, J.M., Gracia, A., and Sanchez, M., 2000. Market segmentation and willingness to pay for organic products in Spain. International Food and Agribusiness Management Review, 3, 207- 226.

Gogoi, B., 2013. Study of antecedents of purchase intention and its effect on brand loyalty of private label brand of apparel, International Journal of Sales Marking, 3 (2): 73-86.

Gould, S.J., 1988. Consumer attitudes toward health and health care: a differential perspective. Journals of Consumers Affairs, 22 (1), 96-118.

Gracia, A., and Magistris, T., 2007. Organic food product purchase behavior: a pilot study for urban consumers in the South of Italy. Span. Journal of Agriculture Research, 5(4): 439-451.

Hapuarachchi, R.W., 2016. Impact of health consciousness and environmental concern on attitudes and purchase intention of consumers: the organic food market in Sri Lanka. Imperial fulfillment of the requirements for the degree of master of business administration, Jayewardenepura University of Sri Lanka. http://doi. 10.31357/fmscmst.2016.00279

Hughner, R., McDonagh, P., Prothero, A., Shultz, C., Stanton, J., 2007. Who are Organic Food Consumers? A Compilation and Review of Why People Purchase Organic Food. Journal of Consumer Behaviors, 6, 94- 110. 
Kapuge, K.D.L.R., 2016. Determinants of organic food buying behavior: special reference to organic food purchase intention of Sri Lankan customers. Procedia food science, 6, 303-308.

Krystallis, A., and Chryssohoidis, G., 2005. Consumers' willingness to pay for organic food: factors that affect it and variation per organic product type, British Food Journal, 107(4/5): 320-323.

Magnusson, M.K., Arvola, A., Koivisto Hursti, U., Aberg, L., Sjo"den, P.O., 2003. "Choice of organic foods is related to perceived consequences for human health and to environmentally friendly behaviour," 40(2): 109-17.

Mintel., 2000. Organic food and drink retailing, market intelligence unit of the UK economic intelligence unit, London.

Mohamad, S.S., Rusdi, S.D., Hashim, N.H., 2014. Organic Food Consumption Among Urban Consumers: Preliminary Results, Social and Behavioral Sciences 130, 509 - 514.

Narmilan, A., Amuthenie, S., 2015. Demand for organic food products in the urban areas of the Batticaloa District, Sri Lanka, Research Journal of Agriculture Forestry Science 3(11):2126, Available online at www.isca.in, www.isca.me.

Ozguven, N., 2012. Organic foods motivations factors for consumers. Procedia-Social and Behavioral Sciences, 62, 661-665.

Padel, S., Foster, C., 2005. Exploring the gap between attitudes and behaviour: Understanding why consumers buy or do not buy organic food. British Food Journal.

Pandey, D., Kakkar, A., Farhan, M., Khan, T.A., 2019. Factors influencing organic foods purchase intention of Indian customers, Organic Agriculture. https://doi.org/10.1007/s13165018-0240-z.

Rosairo, R., 2006. Are Organic Vegetables a Marketing Failure in Sri Lanka? Journal of Agriculture Science, 2(3).

Shaharudin, Rizaimy, M., Jacqueline, P.J., Mansor, Suhardi, Elias, Jamel, S., 2010. Purchase Intention of Organic Food in Malaysia; A Religious Overview. International Journal of Marketing Studies. 10.5539/ijms.v2n1p96.

Sivathanu, B., 2015. Factors affecting consumer preference towards organic food purchases. Indian Journal of Science Technology, 8 (33).

Stobbelaar, D.J., Casimir, G., Borghuis, J., Marks, I., Meije, L., Zebeda, S., 2006. Adolescent's attitudes toward organic food: A survey of 15 to 16 years old school children. International Journal of Consumer Studies, 31(4): 349- 356.

Sujaya, H., Salins, Meghana, Aithal, P.S., 2018. Organic Agricultural Products: A Comparative Study of India with Other
Economies. International Journal Case Studies in Business, IT Edu (IJCSBE), 2(2) http://doi.org/10.5281/zenodo.2530409.

Tabachnick, B., Fidell, L., 2007. Using Multivariate Statistics. California state university, Northridge.

Tech Sci Research, 2014. India organic food market forecast and opportunities, 2019. Available at https://www.slideshare. net/TechSci_Research/ondia-organic-food-market-forecastandopportunities-2019.

WHO, 2015. Global Health Observatory Data. Non-communicable disease Available at https://www.who.int/gho/ncd/en/.

Wijesinghe, W.P.S., Sivashankar, P., Malkanthi, S.H.P., 2016. Consumer preferences for organic food in Colombo municipal council. Chapter 7 of the Book. "Managerial dilemmas in developing countries: Organizational development, Human Resource Management, Consumer Behaviour, Finance and Tourism, and Hospitality," the Cambridge Scholars Publishing.

Wilkins, J.L., Hillers, V.N., 1994. Influences of pesticide residue and environmental concerns on organic food preference among food cooperative members and non-members in Washington State. Journal of Nutrition Education, 26, 26-33.

Yin, S., Wu, L., Du, L., Chen, M., 2010. Consumer purchase intention of organic food in China. Journal of Science Food Agriculture, 90(8): 1361-7 doi: 10.1002/jsfa.3936.

Zanoli, R., Naspetti, S., 2002. Consumer motivations in the purchase of organic food, British food journal, 14(8): 643-653. 
